\title{
Tectonic Geomorphology of Atrak River, NE Iran
}

\author{
Elahe Javadi Mosavi, Mehran Arian* \\ Department of Geology, Science and Research Branch, Islamic Azad University, Tehran, Iran \\ Email: " mehranarian@yahoo.com
}

Received 9 February 2015; accepted 7 March 2015; published 12 March 2015

Copyright (C) 2015 by authors and Scientific Research Publishing Inc.

This work is licensed under the Creative Commons Attribution International License (CC BY). http://creativecommons.org/licenses/by/4.0/

(c) (i) Open Access

\begin{abstract}
Atrak River region, northeast Iran is a quaternary tectonically active region. There are many geologic structures that they are formed by the collision of the Arabian and Eurasian plates. This area has extended from north east Iran to the of kope dagh zone. The study area is Atrak river basin and it has been divided to 56 Sub-basin for calculation of 6 geomorphic indices. Finally, this region was classified in 4 relative tectonic activity classes.
\end{abstract}

Keywords

Atrak, Kope Dagh, Geomorphology, River, Basin, Iran

\section{Introduction}

Neotectonics is a major factor controlling landform development in quaternary tectonically active regions. The effect factors in morphology region are tectonics, lithology, climate and human. If tectonic has been most effective factor in region, it's related to tectonic geomorphology. The study area (Figure 1) of Atrak River basin is at north east of Iran [1] [2]. The river is located in the Kope dagh and Atrak basin is divided to 56 sub-basins (Figure 2).

This area belongs to Kope dagh province [3]. Dominant structural trend in Kope dagh province (Figure 3) is NW-SE. From tectonics view, it contains the Kope dagh hinterland or Kope dagh fold and thrust belt that formed in passive margin of Eurasian plate until late Triassic and then marine sedimentation on Kope Dagh proforeland basin has continued to Eocene. Kope dagh hinterland has uplifted related to Karakorum foreland basin in northeast along Eshghabad fault.

The western part of studied area has located in South Caspian foreland basin. Dominant structural trend in

${ }^{*}$ Corresponding author.

How to cite this paper: Mosavi, E.J. and Arian, M. (2015) Tectonic Geomorphology of Atrak River, NE Iran. Open Journal of Geology, 5, 106-114. http://dx.doi.org/10.4236/ojg.2015.53010 


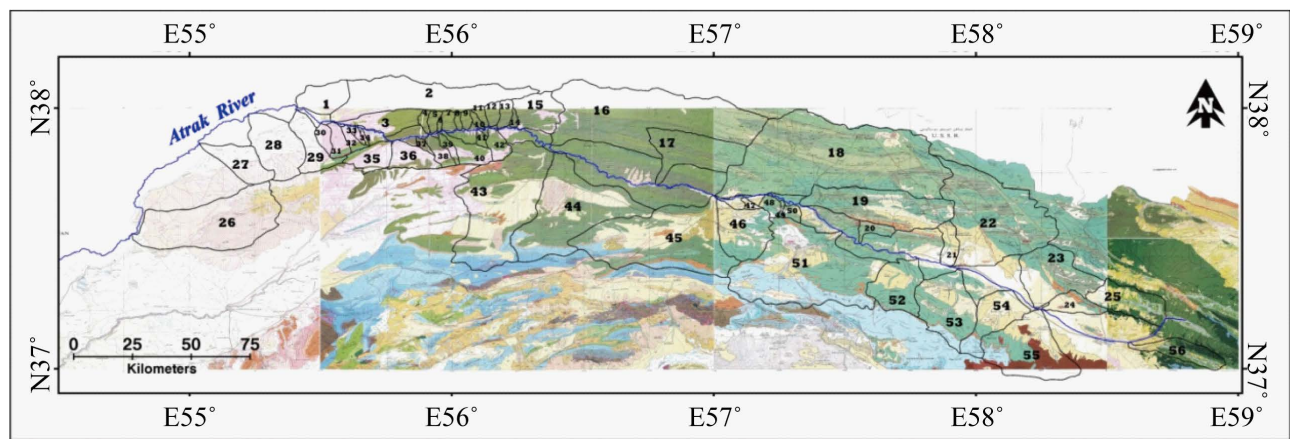

Figure 1. Location of the study area.

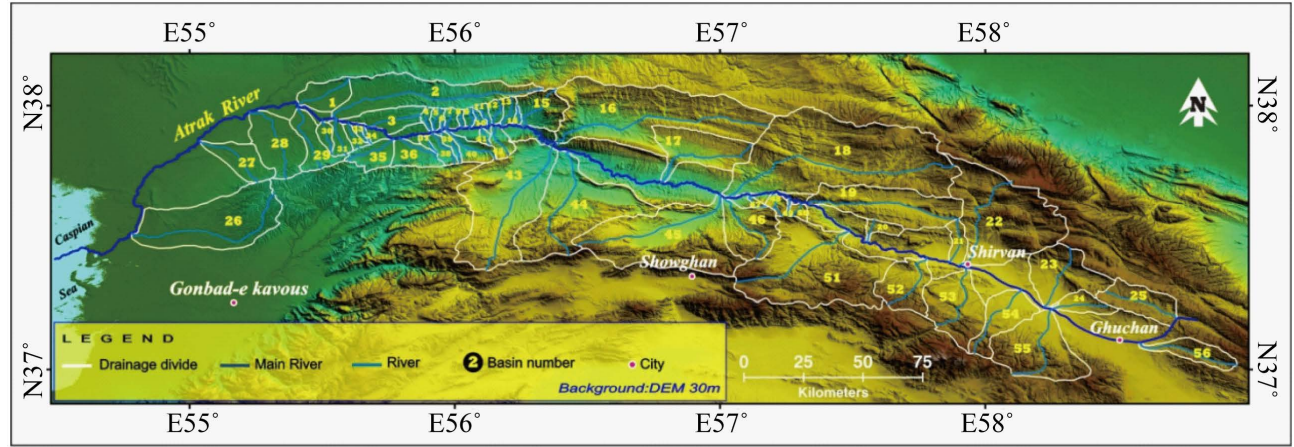

Figure 2. Fifty six sub-basins of the Atrak River basin.

South Caspian foreland basin province (Figure 3) is NW-SE. From tectonics view, it contains the northern foreland basin of West-Central Alborz and lesser Caucasus hinterland in the south margin of Eurasian plate since late Eocene. Although median part of South Caspian and Black sea basin has uplifted by collision between Eurasian and Cimmerian plates [3].

This area has semi active tectonics regim in compared to Alborz [4]-[11], Central Iran [12]-[18] and Zagros in the southern Iran [19]-[22].

\section{Materials and Methods}

This article applies a quantitative geomorphologic method to an area in the Zagros to evaluate rates of active tectonics. Considering the diversity of the morphotectonic features [23] [24]. Spatial tools including geographic information systems (GIS) and morphometric analyses may provide useful information on this subject, we have analyzed below geomorphic indices by [25] method (Table 1). Also, results were shown in Figure 4.

To study the indices, there is a formula which we turn to describe each one of indices; It is necessary to have some primary maps to calculate the indices, and the most important of which are: Digital Elevation Model (DEM), the drainage network and the sub-basins map of the Atrak basin that have been extracted from DEM. DEM (SRTM) extracted from a digitized topographic map (1:30,000).

1 -the stream-gradient index (SL): $\mathrm{SL}=(\Delta \mathrm{H} / \Delta \mathrm{L}) \mathrm{L}$;

2 -drainage basin asymmetry $(\mathrm{Af}): \mathrm{Af}=(\mathrm{Ar} / \mathrm{At}) 100$;

3-hypsometric integral (Hi): $\mathrm{Hi}=($ average elevation - min. elev. $) /($ max. elev. - min. elev. $)$;

4-valley floor width-valley height ratio (Vf): $\mathrm{V} f=2 \mathrm{~V} f \mathrm{w} /($ Ald + Ard $-2 \mathrm{Asc})$;

5—drainage basin shape $(\mathrm{Bs}): \mathrm{Bs}=\mathrm{Bl} / \mathrm{Bw}$;

6-mountain-front sinuosity index (Smf): $\mathrm{J}=\mathrm{Lj} / \mathrm{Ls}$.

\section{Results and Discussion}

We computed a single index (Iat) from the six indices to characterize relative active tectonics. Previous studies in Iran [26]-[42] tend to focus on a particular mountain front or area to discuss relative tectonic activity and 


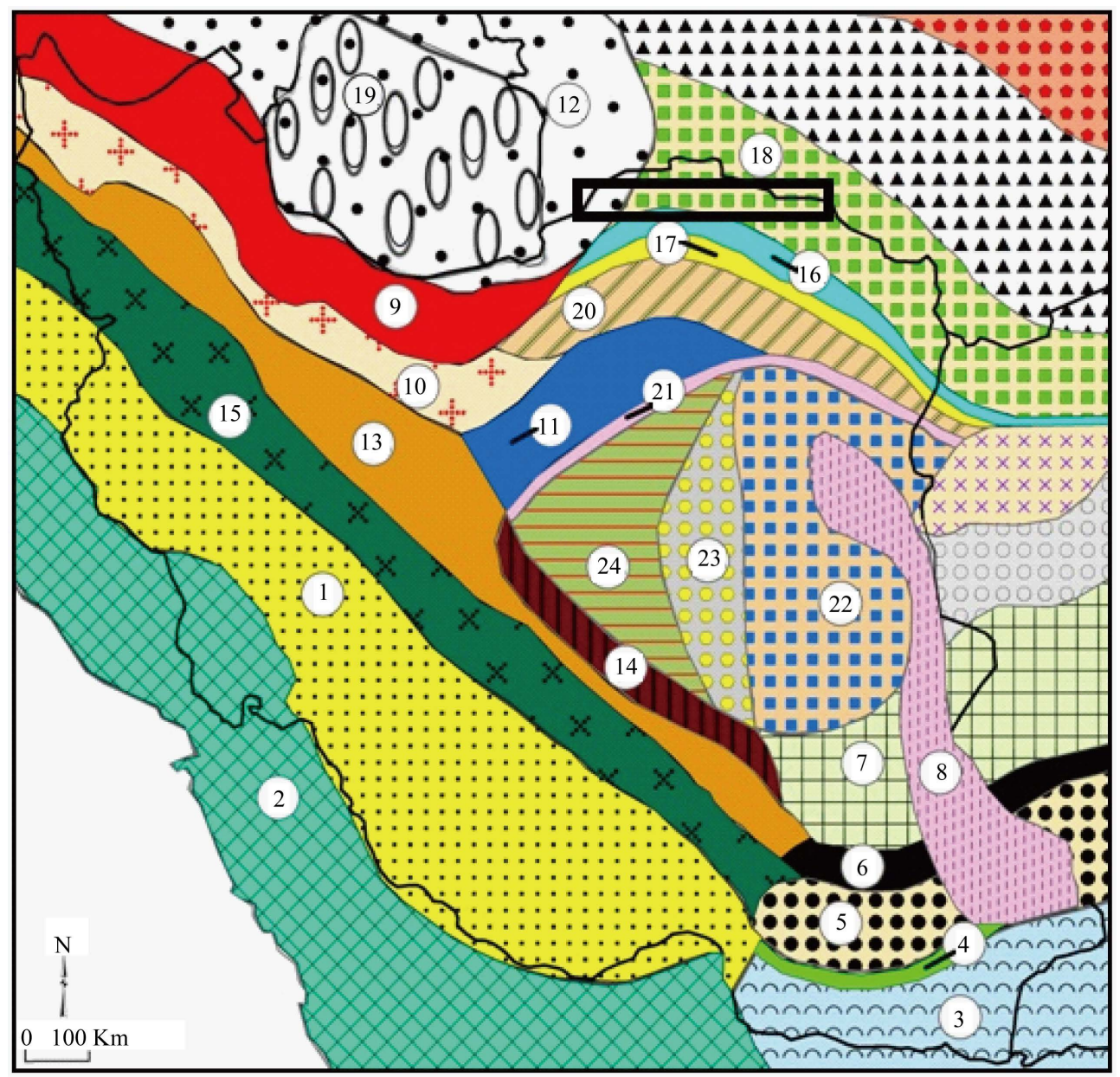

Figure 3. Physiographic-tectonic zoning map of Iran's sedimentary basins Iran, modified from [10]. Numbers in this figure are, 1: Zagros-East Taurus hinterland, 2: Persian Gulf-Mesopotamian foreland basin, 3: Makran accretionary prism, 4: Bashagard Mountains, 5: Jazmorian-Mashkel fore arc basin, 6: Shahsavaran-Soltan magmatic arc, 7: South Lut-South Helmand back arc basin, 8: East Iran Mountain belt, 9: West-Central Alborz and lesser Caucasus hinterland, 10: Great Kavir-Northen Urmieh lake foreland basin, 11: South Great Kavirfold and thrust belt, 12: South CaspianBlack sea foreland basin, 13: Urmieh-Dokhtar Magmatic Arc, 14: Naien-Kerman retro arc foreland basin, 15: Sanandaj-Sirjanoverthrust belts, 16: East Alborz or Binalod hinterland, 17: Torbat-e am-Neyshabour retro arc foreland basin, 18: Kope Dagh hinterland, 19: South Caspian remnant basin, 20: Maiamay-Taibad Inverted back arc basin, 21: Khaf-Kavir Plain Magmatic Arc, 22: Lut Plain-Gonabad back arc basin, 23: Tabas hinterland, 24:Yazd-Khour Piggy back basin. The study area is shown in the black rectangle.

Table 1. Range of geomorphic indices, based on [25].

\begin{tabular}{cccc}
\hline Geomorphic index & Class 1 & Class 2 & Class 3 \\
\hline Vf & $\mathrm{Vf}<0.3$ & $0.3<\mathrm{Vf}<1$ & $\mathrm{Vf}>1$ \\
$\mathrm{~J}$ & $\mathrm{~J}<1.1$ & $1.1<\mathrm{J}<1.5$ & $\mathrm{~J}>1.5$ \\
$\mathrm{Bs}$ & $\mathrm{Bs}>4$ & $3<\mathrm{Bs}<4$ & $\mathrm{Bs}<3$ \\
$\mathrm{Af}$ & $\mathrm{Af}<35$ or Af $>63$ & $57<\mathrm{Af}<65$ or $35<\mathrm{Af}<43$ & $43<\mathrm{Af}<57$ \\
$\mathrm{Sl}$ & $\mathrm{Sl}>500$ & $300<\mathrm{Sl}<500$ & $\mathrm{Sl}<300$ \\
$\mathrm{Hi}$ & $\mathrm{Hi}>0.5$ & $0.4<\mathrm{Hi}<0.5$ & $\mathrm{Hi}<0.4$ \\
\hline
\end{tabular}



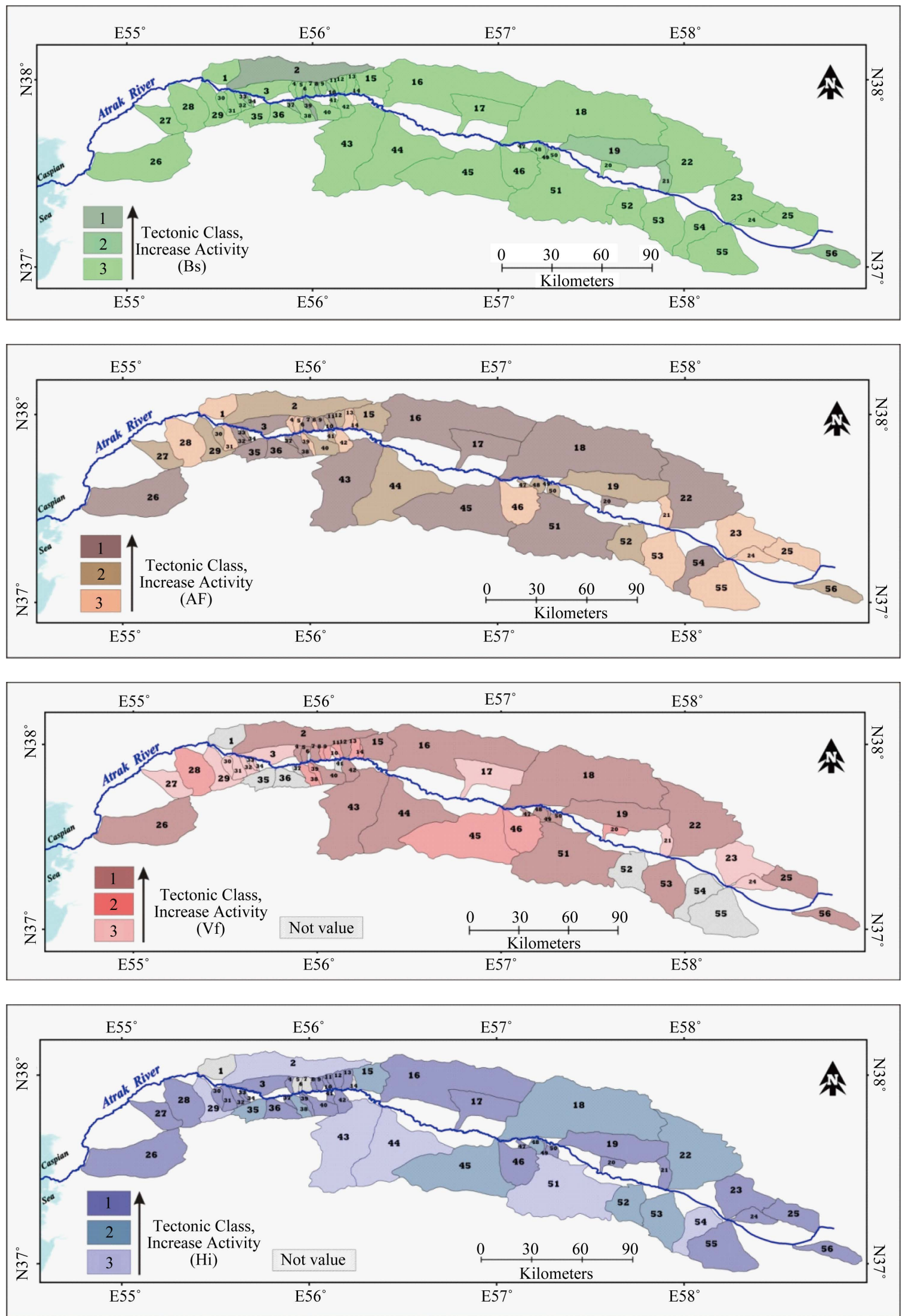

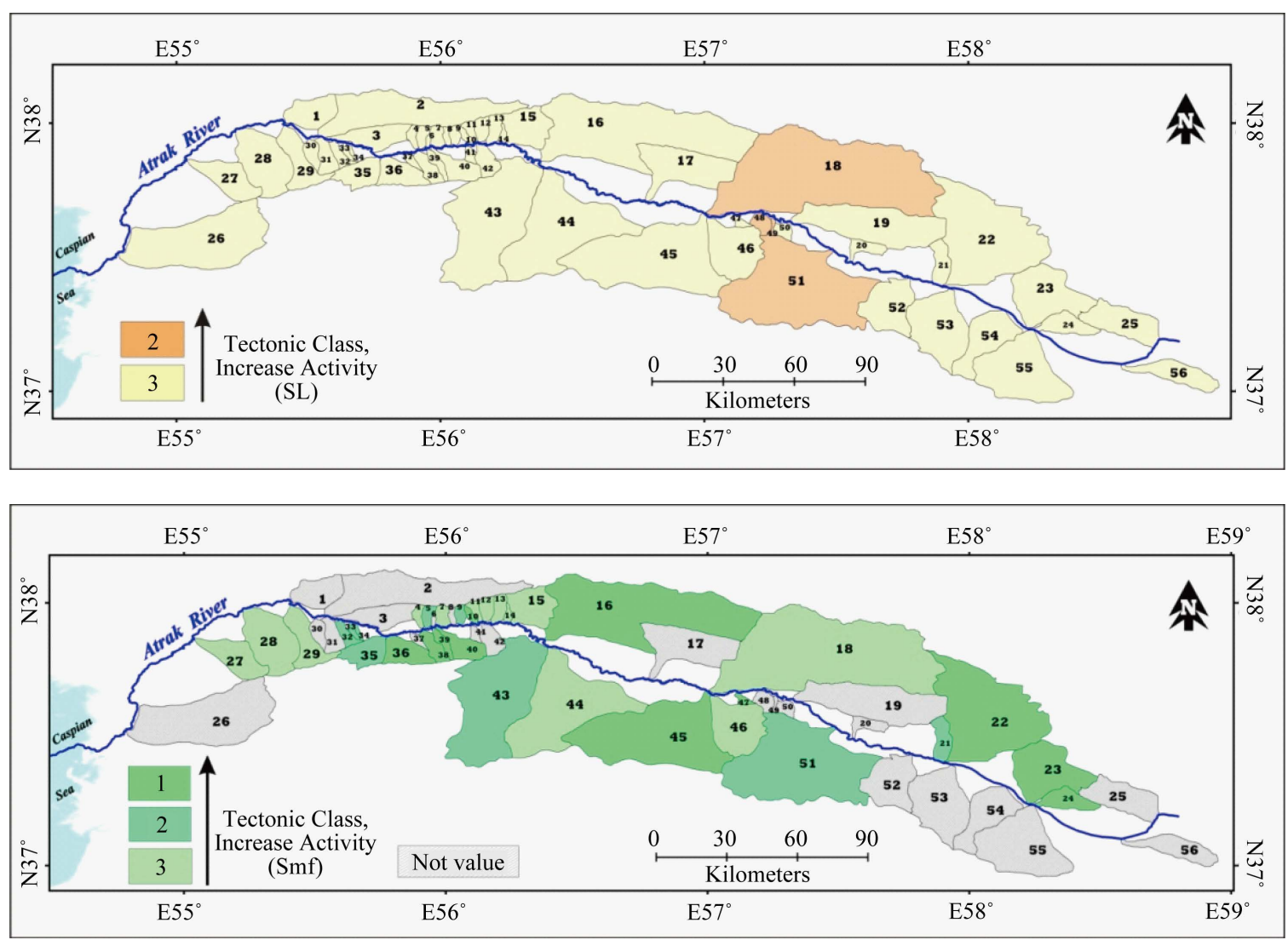

Figure 4. Distribution of six indices and classification of them into three classes.

geomorphic indices [42]-[47]. This study tried to evaluate tectonics in a wider area, using a number of geomorphologic parameters. The average of the six measured geomorphic indices (Iat) was used to evaluate the distribution of relative tectonic activity in the study area. The values of the index were divided into four classes to define the degree of active tectonics: 1 -very high $(1.0 \leq$ Iat $<1.5)$; 2 -high $(1.5 \leq$ Iat $<2.0)$; 3 -moderate $(2.0 \leq$ Iat $<2.5$ ); and 4 -low $(2.5 \leq$ Iat $)$.

The distribution of the four classes is shown in Figure 4. The values of the six geomorphic indices as well as Iat often change corresponding to the distribution of fault zones. Kope dagh, Ghochan, Kerivan, Esfraien and Chamanbid faults are the structural boundary that they have been changed in deformational history of study area. In study area, the low class of Iat is mainly in the sub-basins of 1, 14, $29 \& 31$ while the other parts of the study area has moderate active tectonics. Table 2 shows the result of the classification for each sub-basin.

\section{Conclusions}

Atrak River, north east Iran is a quaternary tectonically active region. The values of SL, Hi, and Bs were found to be high along major faults and folds. The values of Af show widespread drainage-basin asymmetry related to the tectonic tilting. The values of $J$ suggest that mountain fronts are tectonically active, and the values of $\mathrm{Vf}$ show that many valleys are narrow and deep, suggesting a high rate of incision associated with tectonic uplift.

About the whole of the study area has Iat values of classes 2 and 3, indicating moderately to highly active tectonics. Class 2 of Iat, indicative of highly active tectonics, occurs mainly along the fault zone. These classes also correspond well to the areas with prominent scarps of tectonic origin, triangular facets, deformed alluvial fans, and deep narrow gorges.

\section{Acknowledgements}

This work has funded by the Department of geology, Islamic Azad University, Science and Research branch, 
E. J. Mosavi, M. Arian

Table 2. Values of Lat.

\begin{tabular}{|c|c|c|c|c|c|c|c|c|c|}
\hline Basin & $\begin{array}{c}\text { Bs } \\
\text { Tectonic } \\
\text { Class }\end{array}$ & $\begin{array}{c}\text { AF } \\
\text { Tectonic } \\
\text { Class }\end{array}$ & $\begin{array}{c}\mathbf{T} \\
\text { Tectonic } \\
\text { Class }\end{array}$ & $\begin{array}{c}\text { Vf } \\
\text { Tectonic } \\
\text { Class }\end{array}$ & $\begin{array}{c}\text { Hi } \\
\text { Tectonic } \\
\text { Class }\end{array}$ & $\begin{array}{c}\text { SL } \\
\text { Tectonic } \\
\text { Class }\end{array}$ & $\begin{array}{c}\text { Smf } \\
\text { Tectonic } \\
\text { Class }\end{array}$ & $\begin{array}{c}\text { Iat } \\
\text { Detail of } \\
\text { Average }\end{array}$ & $\begin{array}{c}\text { Iat } \\
\text { Tectonic Class }\end{array}$ \\
\hline 1 & 3 & 3 & 3 & - & - & 3 & - & 3.00 & 3 (Low Activity) \\
\hline 2 & 1 & 2 & 3 & 1 & 3 & 3 & - & 2.17 & 2 (Moderate Activity) \\
\hline 3 & 3 & 1 & 3 & 3 & 1 & 3 & _ & 2.33 & 2 \\
\hline 4 & 3 & 3 & 3 & 1 & 1 & 3 & 3 & 2.43 & 2 \\
\hline 5 & 3 & 3 & 2 & 1 & - & 3 & 2 & 2.33 & 2 \\
\hline 6 & 2 & 2 & 2 & _ & _- & 3 & _ & 2.25 & 2 \\
\hline 7 & 3 & 1 & 2 & 1 & - & 3 & 3 & 2.17 & 2 \\
\hline 8 & 2 & 3 & 2 & 2 & 1 & 3 & _ & 2.17 & 2 \\
\hline 9 & 3 & 1 & 1 & 2 & 1 & 3 & 2 & 1.86 & 2 \\
\hline 10 & 2 & 2 & 3 & 3 & 1 & 3 & 1 & 2.14 & 2 \\
\hline 11 & 3 & 1 & 1 & 2 & 1 & 3 & 3 & 2.00 & 2 \\
\hline 12 & 3 & 2 & 1 & 1 & 1 & 3 & 3 & 2.00 & 2 \\
\hline 13 & 3 & 3 & 2 & 2 & 1 & 3 & 3 & 2.43 & 2 \\
\hline 14 & 3 & 3 & 2 & 2 & - & 3 & 3 & 2.67 & 3 \\
\hline 15 & 3 & 2 & 1 & 1 & 2 & 3 & 3 & 2.14 & 2 \\
\hline 16 & 3 & 1 & 1 & 1 & 1 & 3 & 1 & 1.57 & 2 \\
\hline 17 & 3 & 1 & 2 & 3 & 1 & 3 & - & 2.17 & 2 \\
\hline 18 & 3 & 1 & 2 & 1 & 2 & 2 & 3 & 2.00 & 2 \\
\hline 19 & 2 & 2 & 2 & 1 & 1 & 3 & - & 1.83 & 2 \\
\hline 20 & 3 & 1 & 2 & 2 & 1 & 3 & - & 2.00 & 2 \\
\hline 21 & 2 & 3 & 2 & 3 & 1 & 3 & 2 & 2.29 & 2 \\
\hline 22 & 3 & 1 & 1 & 1 & 2 & 3 & 1 & 1.71 & 2 \\
\hline 23 & 3 & 3 & 3 & 3 & 1 & 3 & 1 & 2.43 & 2 \\
\hline 24 & 3 & 3 & 2 & 3 & 1 & 3 & 1 & 2.29 & 2 \\
\hline 25 & 3 & 3 & 3 & 1 & 1 & 3 & - & 2.33 & 2 \\
\hline 26 & 3 & 1 & 1 & 1 & 1 & 3 & - & 1.67 & 2 \\
\hline 27 & 3 & 2 & 1 & 3 & 1 & 3 & 3 & 2.29 & 2 \\
\hline 28 & 3 & 3 & 2 & 2 & 1 & 3 & 3 & 2.43 & 2 \\
\hline 29 & 3 & 2 & 2 & 3 & 3 & 3 & 3 & 2.71 & 3 \\
\hline 30 & 3 & 2 & 2 & 3 & 1 & 3 & - & 2.33 & 2 \\
\hline 31 & 3 & 3 & 2 & 3 & 1 & 3 & - & 2.50 & 3 \\
\hline 32 & 3 & 1 & 2 & 3 & 1 & 3 & 2 & 2.14 & 2 \\
\hline 33 & 2 & 1 & 1 & 3 & 1 & 3 & 2 & 1.86 & 2 \\
\hline 34 & 1 & 2 & 2 & 3 & 1 & 3 & 2 & 2.00 & 2 \\
\hline 35 & 3 & 1 & 2 & - & 2 & 3 & 2 & 2.17 & 2 \\
\hline 36 & 3 & 1 & 1 & - & 1 & 3 & 1 & 1.67 & 2 \\
\hline 37 & 2 & 1 & 1 & - & 1 & 3 & - & 1.60 & 2 \\
\hline
\end{tabular}




\begin{tabular}{|c|c|c|c|c|c|c|c|c|c|}
\hline \multicolumn{10}{|c|}{ Continued } \\
\hline 38 & 3 & 1 & 1 & 2 & 2 & 3 & 1 & 1.86 & 2 \\
\hline 39 & 1 & 3 & 2 & 2 & 1 & 3 & 1 & 1.86 & 2 \\
\hline 40 & 3 & 2 & 2 & 1 & 1 & 3 & 1 & 1.86 & 2 \\
\hline 41 & 3 & 2 & 3 & - & 1 & 3 & - & 2.40 & 2 \\
\hline 42 & 3 & 3 & 2 & 1 & 1 & 3 & - & 2.17 & 2 \\
\hline 43 & 3 & 1 & 2 & 1 & 3 & 3 & 2 & 2.14 & 2 \\
\hline 44 & 3 & 2 & 1 & 1 & 3 & 3 & 3 & 2.29 & 2 \\
\hline 45 & 3 & 1 & 1 & 2 & 2 & 3 & 1 & 1.86 & 2 \\
\hline 46 & 3 & 3 & 2 & 2 & 1 & 3 & 3 & 2.43 & 2 \\
\hline 47 & 3 & 2 & 2 & 1 & 1 & 3 & 1 & 1.86 & 2 \\
\hline 48 & 3 & 2 & 2 & 1 & 2 & 2 & - & 2.00 & 2 \\
\hline 49 & 2 & 3 & 2 & 1 & 1 & 2 & - & 1.83 & 2 \\
\hline 50 & 3 & 2 & 2 & 1 & 1 & 3 & - & 2.00 & 2 \\
\hline 51 & 3 & 1 & 3 & 1 & 3 & 2 & 2 & 2.14 & 2 \\
\hline 52 & 3 & 2 & 2 & - & 2 & 3 & - & 2.40 & 2 \\
\hline 53 & 3 & 3 & 2 & 1 & 2 & 3 & - & 2.33 & 2 \\
\hline 54 & 3 & 1 & 1 & - & 3 & 3 & - & 2.20 & 2 \\
\hline 55 & 3 & 3 & 2 & - & 1 & 3 & - & 2.40 & 2 \\
\hline 56 & 2 & 2 & 3 & 1 & 1 & 3 & _ & 2.00 & 2 \\
\hline
\end{tabular}

Iat classification: 1 (High Activity), 2 (Moderate Activity), 3 (Low Activity).

Tehran, Iran. Also, Special thanks to vice-president for research in Science and Research branch, Tehran.

\section{References}

[1] Qorashi, M. and Arian, M. (2011) Tectonics of Iran. Geologic Survey of Iran, 336 p. (In Persian)

[2] Arian, M. (2011) Basement Tectonics and Geology of Iran. Asar Nafis Press, 300 p. (In Persian)

[3] Arian, M. (2013) Physiographic-Tectonic Zoning of Iran’s Sedimentary Basins. Open Journal of Geology, 3, $169-177$.

[4] Arian, M., Maleki, Z. and Noroozpour, H. (2011) Cenozoic Diastrophism and Deformational Events in the East-Central Alborz. Journal of Basic and Applied Scientific Research, 1, 2394-2400.

[5] Feizi, F., Arian, A. and Rahmani, R. (2007) Seismotectonic Zoning in the Eastern Part of the Central Alborz. Journal of Sciences, Islamic Azad University, 17, 151-164. (In Persian)

[6] Nouri, R., Jafari, M.R., Arian, M., Feizi, F. and Afzal, P. (2013) Correlation between Cu Mineralization and Major Faults Using Multifractal Modelling in the Tarom Area (NW Iran). Geologica Carpathica, 64, 409-416.

[7] Nouri, R., Afzal, P., Arian, M., Jafari, M. and Feizi, F. (2013) Reconnaissance of Copper and Gold Mineralization Using Analytical Hierarchy Process (AHP) in the Rudbar 1:100,000 Map Sheet, Northwest Iran. Journal of Mining and Metallurgy A: Mining, 49, 9-19.

[8] Poroohan, N., Pour Kermani, M. and Arian, M. (2013) An Assessment of Relationship in F-Parameter and Paleostress Fields in Heterogeneous Lithologies: Roudbar Area (Northwest of Iran). Australian Journal of Basic \& Applied Sciences, 7, 933-942.

[9] Poroohan, N., Kermani, M.P. and Aryan, M. (2009) An Assessment on Correlations of Seismotectonic Parameters Preceding and Following Roudbar-Manjil Earthquake (Gilan, North of Iran). Australian Journal of Basic \& Applied Sciences, 3, 2643-2652.

[10] Arian, M. and Pourkermani, M. (2004) Tectonic Elements of South Flank in the East-Central Alborz Mountain. Journal of Sciences, Teacher Training University, 4, 359-368.

[11] Arian, M. and Qorashi, M. (2006) The Movement Potential Evaluation of the Major Quaternary Faults in Alborz-Central 
Iran Border Zone, from the East of Tehran to the East of Semnan. Journal of Geosciences, Geological Survey of Iran, 15, 184-188.

[12] Pourkermani, M. and Arian, M. (2001) Structural Geomorphology of Northeastern Kurdistan, Sistan and Baluchestan University. Journal of Humanities, 7, 37-48.

[13] Arian, M. (2012) Clustering of Diapiric Provinces in the Central Iran Basin. Carbonates and Evaporites, 27, 9-18. http://dx.doi.org/10.1007/s13146-011-0079-9

[14] Pourkermani, M. and Arian, M. (1997) Salt Domes of Central Iran. Journal of Humanities University of Sistan and Balouchestan, 3, 29-41. (In Persian)

[15] Arian, M., Pourkermani, M., Sistanipour, A. and Noroozpour, H. (2011) Kinematic Significance of Fold- and FaultRelated Fracture Systems in the Rafsanjan’s Northeast Highlands (Central Iran). Journal of Basic and Applied Scientific Research, 1, 3398-3406.

[16] Arian, M., Pourkermani, M., Sistanipour, A. and Noroozpour, H. (2011) Seismicity and Fault Segmentation of BafqBaghin Fault System (Central Iran). Journal of Applied Environmental and Biological Sciences, 1, 382-396.

[17] Asadian, F. and Arian, M. (2009) Identification of Diapiric Provinces of Central Iran through Geological and Geographical Analysis. International Journal of Agriculture Environment \& Biotechnology, 2, 3443-3451.

[18] Arian, M. (2010) Earthquake-Fault Hazard Investigations in the Kerman Quadrangle. Journal of Sciences, Islamic Azad University, 19, 176-182. (In Persian)

[19] Rahimi, N. and Arian, M. (2014) Tectonic Geomorphplogy of Hamedan-Sosangerd Region, West Iran. Advances in Environmental Biology, 8, 119-124.

[20] Arian, M. and Hashemi, A. (2008) Seismotectonic Zoning in the Zagros. Journal of Sciences, 18, 63-76. (In Persian)

[21] Arian, M., Ahmadnia, A., Qorashi, M. and Pourkermani, M. (2002) Structural Analysis of Mengharak Transcurrent Fault System in Zagros, Iran. GeoArabia, 7, 209-210.

[22] Arian, M., Qorashi, M., Pourkermani, M. and Ahmadnia, A. (2006) The Structural Significance Kareh Bas Transcurrent Fault System in the Zagros Fold and Thrust Belt. Journal of Geosciences, Geological Survey of Iran, 15, 126-133. (In Persian)

[23] Burbank, D.W. and Anderson, R.S. (2001) Tectonic Geomorphology. Blackwell Science, Oxford, 274 p.

[24] Keller, E.A. and Pinter, N. (1996) Active Tectonics: Earthquakes, Uplift, and Landscape. Prentice Hall, Englewood Cliff.

[25] El Hamdouni, R., Irigaray, C., Fernandez, T., Chacón, J. and Keller, E.A. (2007) Assessment of Relative Active Tectonics, Southwest Border of Sierra Nevada (Southern Spain). Geomorphology, 96, 150-173.

[26] Arian, M. and Aram, Z. (2014) Relative Tectonic Activity Classification in the Kermanshah Area, Western Iran. Solid Earth, 5, 1277-1291. http://dx.doi.org/10.5194/se-5-1277-2014

[27] Mashal, M., Kermani, M.P., Charchi, A., Almasian, M. and Arian, M. (2013) Pattern of Structural Geology Underground in Eastern of North Dezfol Embayment. Advances in Environmental Biology, 7, 260-268.

[28] Housini Toudeshki, V. and Arian, M. (2011) Morphotectonic Analysis in the Ghezel Ozan River Basin, NW Iran. Journal of Geography and Geology, 3, 258-260.

[29] Pazhoohan, M., Arian, M., Ghorashi, M. and Khosrotehrani, K. (2014) A Study of Drainage Pattern Responses to Active Tectonics in Tadvan Region, SW Iran. Geodynamics, 1, 36-41.

[30] Arian, M., Bagha, N., Khavari, R. and Noroozpour, H. (2012) Seismic Sources and Neo-Tectonics of Tehran Area (North Iran). Indian Journal of Science and Technology, 5, 2379-2383.

[31] Arian, M., Pourkermani, M., Sistanipour, A. and Noroozpour, H. (2011) Seismicity and Fault Segmentation of Bafq-Baghin Fault System (Central Iran). Journal of Applied Environmental and Biological Sciences, 1, 382-396.

[32] Bagha, N., Arian, M., Ghorashi, M., Pourkermani, M., El Hamdouni, R. and Solgi, A. (2014) Evaluation of Relative Tectonic Activity in the Tehran Basin, Central Alborz, Northern Iran. Geomorphology, 213, 66-87. http://dx.doi.org/10.1016/j.geomorph.2013.12.041

[33] Arian, M. and Feizi, F. (2005) Application of Geomorphic Indices to the Assessment of Relative Tectonic Activity Levels in the Alborz-Central Iran Border Zone (From the East of Varamin to the East of Semnan). Journal of Sciences (Islamic Azad University), 15, 378-403.

[34] Khavari, R., Arian, M. and Ghorashi, M. (2009) Neotectonics of the South Central Alborz Drainage Basin, in NW Tehran, N Iran. Journal of Applied Sciences, 9, 4115-4126. http://dx.doi.org/10.3923/jas.2009.4115.4126

[35] Arian, M. and Bagha, N. (2012) Active Tectonics of Tehran Area, Iran. Journal of Basic and Applied Scientific Research, 2, 3805-3819.

[36] Arian, M., Toudeshki, V.H. and Noroozpour, H. (2011) Active Tectonics of Qezel Ozan River Basin, NW Iran. Jour- 
nal of Applied Environmental and Biological Sciences, 1, 291-295.

[37] Housini Toudeshki, V., Pourkermani, M., Arian, M. and Khosrotehrani, K.H. (2011) Influence of Structures on the Ghezel Ozan River. Geosciences, 21, 55-60.

[38] Mardani, Z., Ghorashi, M. and Arian, M. (2011) Geomorphic Signatures of Active Tectonics in the Talaghan Rud, Shah Rud and Sefidrud Drainage Basins in Central Alborz, N Iran. Geosciences, 20, 159-166.

[39] Sorbi, A., Arian, M. and Pourkermani, M. (2011) The Application of Geomorphic Indices to the Assessment of Relative Tectonic Activity Levels in Tehran Quadrangle. Journal of the Earth, 6, 1-9.

[40] Khavari, R., Ghorashi, M., Arian, M. and Khosrotehrani, K. (2010) Geomorphic Signatures of Active Tectonics in the Karaj Drainage Basin in South Central Alborz, N Iran. Geosciences Scientific Quarterly Journal, 19, 67-74.

[41] Arian, M. and Noroozpour, H. (2015) The Biggest Salt-Tongue Canopy of Central Iran. Open Journal of Geology, 5, 55-60. http://dx.doi.org/10.4236/ojg.2015.52005

[42] Arian, M. and Noroozpour, H. (2015) Tectonic Geomorphology of Iran’s Salt Structures. Open Journal of Geology, 5, 61-72. http://dx.doi.org/10.4236/ojg.2015.52006

[43] Azor, A., Keller, E.A. and Yeats, R.S. (2002) Geomorphic Indicators of Active Fold Growth: South Mountain-Oak Ridge Ventura Basin, Southern California. Geological Society of America Bulletin, 114, 745-753. http://dx.doi.org/10.1130/0016-7606(2002)114<0745:GIOAFG>2.0.CO;2

[44] Bull, W.B. and McFadden, L.D. (1977) Tectonic Geomorphology North and South of the Garlock Fault, California. Proceedings of the Eighth Annual Geomorphology Symposium, Binghamton, 23-24 September 1977, 115-138.

[45] Molin, P., Pazzaglia, F.J. and Dramis, F. (2004) Geomorphic Expression of Active Tectonics in a Rapidly-Deforming Forearc, Sila Massif, Calabria, Southern Italy. American Journal of Science, 304, 559-589. http://dx.doi.org/10.2475/ajs.304.7.559

[46] Farrokhnia, A., Pirasteh, S., Pradhan, B., Pourkermani, M. and Arian, M. (2011) A Recent Scenario of Mass Wasting and Its Impact on the Transportation in Alborz Mountains, Iran Using Geo-Information Technology. Arabian Journal of Geosciences, 4, 1337-1349.

[47] Rockwell, T.K., Keller, E.A. and Johnson, D.L. (1985) Tectonic Geomorphology of Alluvial Fans and Mountain Fronts near Ventura, California. In: Morisawa, M., Ed., Tectonic Geomorphology, Allen and Unwin Publishers, Boston, 183-207. 